\title{
Laws and Policies Enacted by the United States for Immigration and the Impacts
}

\author{
Zi'ang $\mathrm{Li}^{1}{ }^{1, *}$ \\ ${ }^{1}$ High School Affiliated to Renmin University of China, Beijing, 100055 \\ *Corresponding author. Email: JustinLi0012021@163.ocm
}

\begin{abstract}
Many of the great events in American history began with the arrival of immigrants. More than four hundred years ago, with the arrival of the British, the United States gradually changed from an Indian tribal system to a mixed agricultural system of farms, which signifies the fundamental institution of American crops and cultivation; Approximately 300 years ago, western Europeans fleeing famine came to the United States, providing the states with the means of production and advanced technology learning from Industrial Revolution, which brought the United States Taylorism; nearly 200 years, due to the demand of gold rush, countless of Asian immigrants chose to reside in the U.S, passingly promote the occurrence of the Gilded Age and the development of Atlantic Railroad. In these cases, immigrants played inseparable roles in shaping the identity of the U.S. To deal with the essential part of a nation, America pertinently issued lots of statutes for the past four hundred years, each of which deeply influenced the demand and supply of immigrants from different countries. Three of the most representative ethnic groups were selected as aggregate samples. By comparing the laws of three different reference objects, this paper analyzes the differences in the treatment of immigrants in the United States and the subsequent development of the three ethnic groups in the United States. The purpose of this paper is to explore the restrictive policies and effects of foreign immigration in the United States. In the process of research, the investigation will show how America and immigrants respond to their own needs and social environment to some extent can be drawn.
\end{abstract}

Keywords: Puritans, Mexico, Asia, Population Change, Immigration Acts

\section{INTRODUCTION}

From the beginning of the execution of immigrated policies, exotic hopes and prospects lit up by the United States have gradually embraced with capitalism's intangible hug. Treated with unfair People who sought for freedom and progress were eager to the precious chance of which they could be debarking on a promising land. As the time elapsed, the United States has raised a great mass fervor of immigration, attracting nearly 43.70 million people's attentions.

However, not in the minority, British, Mexicans, and Asians are taking in great parts of who would rather be the illicit stowaways under the gaps of law than the qualified immigrants through regular process. In the face of great immigration, United States has established, modified, and improved countless legislated policies of which to cope with such intractable problems back and forth.
In order to analyze the unstoppable tendency of which the immigrants are eager to resettle in the land of emerging capitalism, the comparison between each race and pertinent published legal policies seems quite significant. This paper introduces several immigration trends and relevant laws in the United States, through comparison to show the impacts of these immigration laws and policies.

\section{SEVERAL IMMIGRATION TRENDS AND RELEVANT LAWS IN THE UNITED STATES}

\subsection{European immigration}

The immigration history of Europeans is wellfounded. From the point of view of the founding of the United States, there is no doubt that the Europeans, especially the British, played a very important role. [1] However, the reason for the mass migration of Europeans was not only to expand their territory but more to escape 
and resist the domestic policy repression of the Europeans at that time. A few years after the founding of Jamestown, England's Henry VIII carried out a series of religious reforms, such as radical religious reform, but caused a religious division in England. People who were dissatisfied with Henry VIII's religious reform were called Puritans. They started a movement against the English king. Religious divisions grew. Puritans from the Church of England came to America to escape religious persecution for their opposition to the Church of England. At the time, Britons in the United States could gain American status through political asylum. An applicant can be granted refugee status if either the Immigration Office or the Immigration Courts believe that the applicant has suffered persecution or that the applicant has a reasonable fear of persecution. Supported and attracted by American policies, a large group of English Puritans boarded the Mayflower, which was full of hope and freedom. Mand more future generations of Europe have been willing to retrace the liberal and hopeful paths of their progressive forebears. However, this seemingly glorious road also has many challenges.

The United States in its early days only welcomed people from Western and Northern Europe, not from other parts of Europe. This point was related to the development and affluence of the countries at that time. "Germany, Britain, and Ireland had left most of northern and southern Europe far behind by the advance of the first industrial revolution" [2]. The United States, eager for technology, drew on European talent and Labor in an endless stream. Incidentally, there was an unprecedented famine in Europe, and the United States had to limit the number of immigrants from Europe because of the enormous number of refugees to emigrate.

The United States Congress passed the Immigration Act of 1921 and the Immigration Act of 1924, the core of which is the immigration quota system. "The new immigration law decided to use the 1890 U.S. census as the basis for each country's annual quota of new immigrants, based on the proportion of the country of origin of the existing population" [3]. Later, the KnowNothing Party put forward that "only the native Americans are the American people", which directly led to the stereotype of the European immigrants. Because of the scarcity of social resources and the increase of unemployment at home, Americans began to resist harshly. So far the States, because of its identity and ethnic structure, has been more friendly to immigrants from Europe than from other countries.

However, European immigrants are not necessarily representative. As the first pioneer disembarking in the new land, the English Pilgrims who landed on the Mayflower made up a large part of the American population. As a result, Europe's immigration policy to the United States will be looser than that of other countries. In order to focus on more representative immigration policies and changes, the Mexican nation located in the southern part of the United States and the Asian nation far away in the mysterious east will bring different perspectives. In view of the immigration needs of these two places, the United States government has made policies to attract to different degrees.

\subsection{Mexican immigration}

The migration of Mexicans to the United States is a complex and changing socio-historical process dating back to the 1850s. It is well known that what is now the southwestern territory of the United States belonged to Mexico before the Mexican-American War. Mexicans lived there centuries before the United States was born. On May 13, 1846, the war began. The war ended in defeat for Mexico, and on February 2, 1848, the two countries signed the Treaty of Guadalupe Hidalgo. The northwestern territory of Mexico was ceded to the United States, including present-day California, Utah, Nevada and Arizona. Parts of New Mexico and Colorado became U.S. territory. The treaty provided that Mexicans living in the former Mexican territory annexed to the United States were free to choose to remain in their current places of residence or to migrate to the Mexican Republic at any time. "As a result of the treaty, nearly 80,000 Mexicans automatically became "Americans", living mainly in present-day Texas, California and New Mexico" [4]. Unlike immigrants from other countries and regions, many Mexicans immigrate to the United States on what was once their territory. Today, a large proportion of Mexican immigrants live in California and Texas. Making this point clear is important to a full understanding of Mexican immigrants in the United States.

After the Mexican-American War, the border between the United States and Mexico remained open, but the number of Mexicans immigrating to the United States did not grow. This open border policy places few or no restrictions on Mexican workers who want to work in the United States. "The United States and Mexico share a 2,000-mile border, making it much easier for Mexicans to move in and out of the United States" [5]. This period was a period of "unrestricted access" from the perspective of the policy attitude of the United States. Uncontrolled and impeded immigration in the 19th century attracted little attention in either country. Until 1900, permanent legal immigration was a relatively small proportion because Mexicans could move informally across the border. Douglas S. Massey, a professor in the Department of Sociology at University of Pennsylvania, and Jorge Durand, a professor at the University of Guadalajara, Mexico, and others argue that it was not until the 20th century that one could officially speak of "international migration" between Mexico and the United States. In short, the Mexican-American border did not always exist as a practical reality. The reification of borders as dividing 
lines of social, economic and political significance is largely a product of the 20th century.

Before 1900, Mexican Immigration to the United States never exceeded 500 a year, according to the Immigration and Naturalization Service (INS) Statistical Yearbook [6]. Besides, the United States Immigration Report suggests that the number of Mexican immigrants admitted to the United States was 109 in 1894, 1,009 in 1904, and 6,067 in 1908, which soared to 16,251 in 1909 [7]. The late 19th and early 20th centuries saw important economic transformations in both the United States and Mexico. Mexico followed a liberal economic path, a time of political stability and economic growth. Development, however, came at a high cost. With the consolidation of rural land ownership, most rural households had lost their land by the first decade of the 20th century. "Agricultural mechanization and the diversion of commodity crops sharply reduced rural job opportunities, and falling wages were accompanied by rising food prices" [8]. As Mexicans continue to migrate from the countryside to the cities, wages in the cities fall. Some Mexicans see immigration to the United States as a safe option.

In 1910, the Mexican Revolution devastated the Mexican economy. From 1910 to 1920, 200,000 Mexicans immigrated to the United States. Emigration did not rise in a straight line during the entire Mexican Revolution but declined to a certain extent and leveled off around 1914. At the same time, the American Southwest experienced rapid economic growth and a significant increase in agricultural production in the early 1900s. Railroads connected the agricultural and mining regions of the Southwest, boosting the industrial cities of the Northeast and Midwest. Along with industrialization came rapid developments in mining, animal husbandry, and agriculture, which required large quantities of cheap labor. In addition, "immigration from Asia abruptly stopped after the Chinese Exclusion Act of 1882 and the Gentleman's Agreement with Japan in 1907, The reduced availability of cheap eastern labor has resulted in a drastic labor shortage in the major sectors of the western economy, especially railroads, mines, agriculture, and construction" [9]. As the demand for workers grew and traditional sources of labor closed, Mexican immigrants entered the sights of American employers. The arrival of Mexican immigrants provided an abundant, continuous, and cheap source of labor for the southwestern economy of the United States. Immigration from Europe was temporarily blocked by the outbreak of World War I in 1914, which coincided with a huge expansion of American industry as a result of the war.

In addition, the conscription of a certain number of American citizens led to a contraction of the labor force. Faced with a shortage of labor, American employers stepped up their recruitment from Mexico. After the war, Mexican immigration continued to increase, and many companies, especially railroad and mining companies, entered Mexico to recruit labor. "Between 1915 and 1920, Mexican immigration increased from 11,000 a year to 51,000. During the 1920s, about half a million Mexicans came into the United States" [10]. In 1924, The United States Congress passed The National Origins Act of 1924 which established a quota system based on the nationality of immigrants. Yet immigration from the "back door" of Mexico and the countries of the Western Hemisphere remained free, and Mexicans became the most important source of immigrant labor in the western United States. According to the 1985 Statistical Yearbook of the Immigration and Naturalization Service of the United States Department of Justice (see Table 1), Mexican immigration continued to increase from 1900 to 1930, and by the end of the $1820 \mathrm{~s}$, Mexicans accounted for $11.2 \%$ of all legal immigrants to the United States.

The stock market crash of October 1929 triggered the Great Depression. As the economy worsened, the U.S. labor market weakened and unemployment reached record levels, topping 10 million in 1932. In this situation, public attitudes toward Mexican immigrants hardened and became hostile, blaming Mexicans for taking their jobs and subsisting on public assistance, making Mexican immigrants scapegoats for unemployment and budget shortfalls. With xenophobia and pressure on Americans on the rise, the Immigration and Naturalization Service launched a deportation program. Between 1929 and 1937 , 458,000 Mexicans were arrested and forcibly deported from the United States, and many "voluntarily" returned to Mexico in the face of great political hostility and poor economic prospects. [11] The repatriated Mexicans are a mix of undocumented and legal immigrants. The first wave of Mexican immigrants retreated.

\subsection{Asian Immigration}

Drawn by America's early westward movement and by the gold mines in California, Asians began to express a yearning for America. In contrast, the United States was amid a labor shortage caused by the development of the West, and California was in dire need of miners. Thus, the needs of both sides are in harmony.

Although Asians, almost all of whom were Chinese, were not in large numbers in the United States in the late 1800 s - making up less than one-tenth of $1 \%$ of the population -- their presence was crucial to shaping American immigration policy. The first major restriction on free immigration to the United States was the Chinese Exclusion Act of 1882, which barred "Chinese laborers" from entering the United States for 10 years. The ban was extended for another ten years in 1892 and made permanent in 1902. So the Chinese were the first group to be excluded, and the 1882 Act was arguably the pivot to all U.S. immigration policy. From then until 1924, the United States' once-free and unrestricted immigration policy were increasingly constrained economically, culturally, and politically. 
By the enactment of the Immigration Act in 1965, there had been a substantial increase in Asian immigration, leading to the demographic recombination of Asian ethnic groups. From 1969 to 1977, the total number of Asian immigrants exceeded 1.1 million, accounting for an increasing proportion of the number of immigrants entering the country [12]. During the transitional period of the 1965 law, Europeans accounted for $35 \%$ of all immigration, while Asians accounted for $14 \%$. Starting in the 1970 s, the proportion of immigrants from Asia began to surpass those from Europe. In 19721974, Asian immigrants accounted for $32 \%$, and European immigrants accounted for 22\%; from 1975 to 1977, Europeans accounted for only $17 \%$ of immigrants, while Asians rose to $35 \%$. In terms of specific numbers, there were 135,472 Asian immigrants during the transition period, an average of 45,000 per year. From 1969 to 1980 , there were 1.84 million Asian immigrants, an average of 16,000 per year with an increase of $372 \%$ over the transitional period. From the perspective of the number of immigrants in various countries, from 1969 to 1977, the number of Chinese immigrants was 196,000, that of Japan was 46,000, that of North Korea was 189,000 , that of the Philippines was 282,000, and that of India was 161,000 . The influx of immigrants has both increased the Asian share of the U.S. population and recombined the Asian share.

Another indication of the large influx of Asian immigrants is the fact that foreign-born Asians in the United States have begun to outnumber native-born Asians. Foreign-born Indians, Koreans and Vietnamese made up more than $70 \%$ of the group in 1980, up from just $40 \%$ before 1960 . The proportion of Chinese also shifted from $61 \%$ American-born to $68 \%$ foreign-born.

Table 1. Changes in the proportion and distribution of Asian groups

\begin{tabular}{|l|l|l|l|l|}
\hline & 1960 & 1970 & 1980 & 1990 \\
\hline Japanese & 52.9 & 41.1 & 20.7 & 12.3 \\
\hline Chinses & 27 & 30.3 & 23.4 & 23.8 \\
\hline Philippine & 20.1 & 23.8 & 22.6 & 20.4 \\
\hline Korean & - & 4.8 & 10.3 & 11.6 \\
\hline Indian & - & - & 11.2 & 11.8 \\
\hline Vitanemese & - & - & 7.1 & 8.9 \\
\hline American ratio & 0.5 & 0.7 & 1.5 & 2.8 \\
\hline
\end{tabular}

Source: Statistical Yearbook of the Immigration and Naturalization Service, 1960-1990.

The change of this structure is mainly reflected in the following two aspects: first, the improvement of the quality of immigrants, which is reflected in the increase in the proportion of professional and technical personnel and managerial personnel, and the higher cultural quality of Asian immigrants. "New immigrants from Asia are by far the most highly specialized group of immigrants coming into our country", said demographer John McCarthy of the RAND Corporation. The second is the change of main body immigrants, while professional and technical personnel and management personnel in the Asian immigrants account for larger proportion, but this kind of situation in the mid 70s began to change, namely the theme of immigration by using professional priorities towards using family reunion terms and not subject to quota restrictions the U.S. company's immediate family, spouses and children under the age of 21 , enjoy the "privilege". These immigrants bring their wives and children and become U.S. citizens a few years later, allowing their parents to enter the country without restrictions. They can also sponsor the entry of their siblings, who in turn can arrange for their spouses and children to immigrate, creating a pattern known as "chain migration".
With the improvement of the quality of Asian immigrants, the rise of economic and social status, Asian groups began to integrate into American society. Since its introduction in 1965, Asian immigrants have naturalized at a higher rate than immigrants from any other region. From 1970 to 1974 , the naturalization rate of Chinese was $38.7 \%$, compared with $20 \%$ in Japan, $45.6 \%$ in the Philippines, and $27.8 \%$ in India. By 1980, these numbers had increased by about $5 \%$ to $15 \%$ year on year. That compares with $20 \%$ from Europe, $22 \%$ from Latin America, and just 3\% from Mexico.

The arrival of large numbers of Asian immigrants has contributed to the development and expansion of ethnic groups. Some organizations are to solve the problems that new immigrants face, such as English classes, job placement, legal advice. Asian groups began to fight for equal rights for citizens, which was carried out in education, with the publication of magazines such as The Bridge and The Asian American Review. Propelled by the civil rights movement, American universities introduced Asian history classes. In the 1974 case Lau v. Nichols, the United States Supreme Court ruled that the San Francisco school system violated the Civil Rights Act of 1964 by not providing special assistance to non-English speaking 
Chinese students. This case has far-reaching implications. It not only establishes the principle of bilingual education for the Chinese but also applies to other Asian groups. This reflects the increasing political consciousness and civic consciousness of the Asian group. In addition, Asians are actively involved in political activities. Some prominent representatives hold government posts or even directly participate in the management of national affairs.

The reasons for the second wave of Asian immigration are not only the changes in American policies but also the driving force of Asian immigration itself. The push is primarily political. Many Asian immigrants, most of them are Koreans and Filipinos, they come to the United States to escape political turmoil and persecution in their home countries. The second is the economic push. After the mid-1960s, some Asian countries began to step into the stage of industrialization, urbanization accelerated, and the unemployment rate increased. In addition, the population of most Asian countries is booming, which brings serious unemployment problems. Not only that, inflation in some countries. These deteriorating economic conditions have given a huge boost to Asian immigration. Finally, the international situation in Asia is turbulent and the frequent wars are also an important impetus. After the armistice of the Korean War, regional conflicts such as the India-Pakistan conflict and the Vietnam War appeared in Southeast Asia, causing many displaced persons and refugees, especially the refugees from Southeast Asia after the mid-1970s, and a large number of them. By 1980, the United States had carried out 10 resettlement programs for Asian refugees, accepting more than 450,000 people. The above three factors played an irreplaceable role in the large number of Asian immigrants immigrating to the United States after the mid-1960s.

The influx of large numbers of Asian immigrants was not intended by US policymakers. To their surprise, in addition to the above analysis of the provisions of the 1965 Act, the restriction of the Act on Asian immigrants was also reflected in the fact that a series of laws were successively passed during the implementation of the 1965 Act to restrict the entry of Asian immigrants. Its prominent manifestations are the Educational Assistance for Health Professionals Act of 1976 and the Eilberg Act of 1977. Congress introduced the Health Professional Education Assistance Act of 1976 to reduce the number of health professionals, required the Department of Labor to remove physicians and surgeons from its Schedule A. The Eilberg Act of 1977 strengthened the administration of employment licenses for foreign professionals and technicians. It would require employers to fill out an "Alien Employment License Application" for foreign professionals they want to hire, and to prove that they have tried to hire U.S. citizens before formal approval could be obtained. In addition, the United States restricts the issuance of Category 5 priority visas, requiring U.S. citizens to be at least 21 years old to apply for entry for their siblings.

The change of the main body of Asian immigrants is a negative effect of the implementation of the 1965 law, which brings new problems to American society and Asian groups. The negative consequences of the change of the main body of Asian immigrants in the 1970s are mainly reflected in three aspects: low culture, abuse of family priority, and internalization.

Table 2. Changes in the main body of Asian immigrants in the 1970s

\begin{tabular}{|c|c|c|c|c|c|c|}
\hline Year & & Chinese & Japanese & Philippine & Korean & Indian \\
\hline 1965-1968 & \multirow{3}{*}{$\begin{array}{l}\text { Work in the service } \\
\text { industry and other } \\
\text { manual labor \& No } \\
\text { English skills }\end{array}$} & $57 \& 25.2$ & $43 \& 13.8$ & $38 \& 3.1$ & $31 \& 7$ & $11 \& 1.7$ \\
\hline 1969-1977 & & $47 \&$ - & $52 \&$ - & $33.7 \&$ - & $40 \&-$ & $13 \&-$ \\
\hline 1980 & & $58 \& 45.8$ & $62 \& 34.7$ & $73 \& 10.5$ & $75 \& 49.5$ & $41 \& 11.6$ \\
\hline
\end{tabular}

Source: Statistical Yearbook of the Immigration and Naturalization Service, 1965-1980 [13]

The last one is a new word, but it is still a very useful generalization of this period. This paper takes Chinese and Korean people as an example. By the early 1980s, $30 \%$ of Chinese garment factories registered in California in the mid-1970s had closed, switched to production, or were operating under capacity. Retail stores owned by North Koreans are in a slump, with one in two likely to close in their first year of operation and two in three within six years. In addition, due to the living area, economic interests, cultural differences, and other reasons, the contradictions between Asian and other ethnic groups have become more prominent. After the 1980s, these contradictions have become a serious problem in American society [14].

\section{CONCLUSION}

It can be understood that newcomers face culture clashes and ostracism. But these seemingly unequal antagonisms are normal. As hosts, though native Americans' rejection of foreigners may be overdone, the source of this stress response is a purer, more authentic sense of identity and national identity. Migrants who choose to survive in this soil are undoubtedly given more opportunities for development and quality of life than 
natives. Therefore, to some extent, immigrants should first consider adapting to the local environment in the United States and integrating into the local social circle. Of course, the history of immigration policy in the United States also points to excessive, slightly aggressive behavior (such as the Chinese Exclusion Act of 1882). As is the case today, the mobility of the Immigrant population in the United States has been slowing down year by year. In the United States, where the barriers to mobility are small, labor mobility is much less common than most economists are trained to believe it to be. In response to such incidents, domestic immigrants have gradually gathered and united, giving minorities the confidence to criticize openly or fight for equal freedom. Both sides expressed different degrees of demand for their own interests, and the legal provisions of immigration constantly stimulated the hearts of immigrants, who have become much more sensitive to those potential and compulsory limitations.

\section{AUTHORS' CONTRIBUTIONS}

This paper is independently completed by Zi'ang $\mathrm{Li}$.

\section{ACKNOWLEDGMENTS}

I would like to thank all those who helped me during this paper writing.

My deepest gratitude firstly goes to Professor Lieberman, and to my TA Jennie Li, for their constant encouragement and guidance. They have walked me through all the stages of the writing of my thesis. Without their consistent and illuminating instruction, this paper could not have reached its present form. Secondly, I would like to thank my beloved family for their considerations and confidence in me all through these months. I also owe my sincere gratitude to senior schoolmates who have already been in the university and gaven me the help and time in working out my problems during the writing of this paper.

\section{REFERENCES}

[1] Douglas M, The New Immigration and Ethnicity in the United States [J] Population Council, vol.21, no.3, 1995, pp. 631-652.

[2] Barrie Trinder, The Industrial Revolution in Europe, 2020.

https://www.erih.net/fileadmin/Mediendatenbank/

[3] Official of the Historian, Chinese Immigration and the Chinese Exclusion Acts, 2018. https://history.state.gov/milestones/1866-1898

[4] Unknown, History of Legal and Illegal Immigration to the United States, August, 2021. https://www.fairus.org/legislation/reports-andanalysis/history-of-us-immigration-laws
[5] U.S. Department of State, U.S. Relations with Mexico, September 16, 2021. https://www.state.gov/u-srelations-with-mexico/

[6] Rafael Alarcon, U.S. Immigration Policy and the Mobility of Mexicans (1882-2005), 2011. https://selc.wordpress.ncsu.edu/files/2013/03/U.S.Immigration-Policy-and-the-Mobility-of-Mexicans. pdf

[7] Cardenas Gilberto, United States Immigration Policy toward Mexico: An Historical Perspective, 1975. https://escholarship.org/uc/item/0fh8773n

[8] Federal Statistical System of the United States, Economic Research Service, 2021. https://www.usa.gov/federal-agencies/economicresearch-service.

[9] Nancy Malan, Chinese Immigration and the Chinese in the United States [J] Chinese Heritage, 2020, pp 45-51.

[10] Emma Israel and Jeanne Batalova, Mexican Immigrants in the United States, November 5, 2020. https://www.migrationpolicy.org/article/mexicanimmigrants-united-states-2019.

[11] Jorge Durand and Douglas S. Massey, Mexican Migration to the United States: A Critical Review [J] The Latin American Studies Association, vol. 27, no. 2, 1992, pp. 3-42(40 pages).

[12] Abby Budiman, Christine Tamir, Lauren Mora, and Luis Noe-Bustamante, Facts on U.S. Immigrants, 2018, August 20, 2020. https://www.pewresearch.org/hispanic/2020/08/20/f acts-on-u-s-immigrants/

[13] U.S. Department of Justice, Statistical Yearbook of the Immigration and Naturalization Service 19501990, April 1992. https://www.ssa.gov/policy/docs/ssb/v68n1/68n1p3 1

[14] Roger D, United States Policy towards Asian Immigrants: Contemporary Developments in Historical Perspctive [J] International Journal, Spring, vol. 48, no. 2, 1993, pp. 310-334. 